ARTICLE

\title{
Structural Changes and Quality of Women's Labour in India
}

\author{
S. Sundari ${ }^{1}$ \\ Published online: 7 October 2020 \\ (C) Indian Society of Labour Economics 2020
}

\begin{abstract}
The primary objective of this paper is to look at the trends and pattern of changes in women's employment structure over years (1983-2018) consequent upon the structural changes in the Indian economy. It also attempts to analyse the quality of women's labour in terms of select parameters. The study finds that there is neither quantitative nor qualitative improvement in women's employment over time on account of structural changes in the economy. There is no ' $U$ ' curve of female labour supply in response to GDP growth and expansion of female literacy, implying that economic growth has not generated adequate jobs for women. It also signifies that women's entry or exit of labour market is influenced by non-economic factors also. There is no major occupational diversification in women's employment despite structural shift of the economy from primary to tertiary sector. Agriculture is still the leading sector in women's employment. The study further reveals that the quality of women's labour is poor. Overcrowding of workforce in agriculture largely as wage labourers, lower earnings, poor literacy levels, large-scale informal employment and most self-employment in the form of unpaid work are indications of women's disadvantaged position in the labour market.
\end{abstract}

Keywords Women $\cdot$ Structural changes $\cdot$ Quality $\cdot$ Casual labour $\cdot$ Selfemployment · Informal employment

\section{Introduction}

Employment of women is considered as a measure of women's economic empowerment and is also an important indicator of women's contribution to economic development. The work participation rate (WPR) of women of India is showing a downward trend in the last few decades. It has declined from $29.6 \%$ in 1983 to $21.9 \%$ in 2011-2012 as per the 38th and 68th rounds of National Sample Survey and further

S. Sundari

sundarimtwu@yahoo.co.in

1 Department of Economics, Mother Teresa Women's University, (A State University),

Kodaikanal, Tamil Nadu 624101, India 
to $16.5 \%$ according to the recently published Periodic Labour Force Survey (PLFS 2017-2018). Not only the work participation rate of women has been declining, the size of women workforce in absolute numbers is also shrinking. It has dropped from 148.59 million in 2004-2005 to 104.1 million in 2017-2018. The falling trend in women's labour market participation has serious implication for the economy because the current demographic structure seems to be favourable to India. India has the largest number of young working population in the age group of 15-34 years and is considered as the youngest country in the world today. The benefits of the demographic dividend ${ }^{1}$ are likely to be deterred if women stay out of work. It is important to note in this context that mere entry into labour market does not imply the economic well-being of women. Quality of employment is equally important as that reflects the status of women in the workforce. An attempt is made in this paper to address the following research questions. How does women's labour market participation respond to GDP growth in India? What are the major structural changes in Indian economy? Has structural changes altered the employment structure of women workforce? Is there improvement in the quality of women's labour?

The study is based on the employment and unemployment surveys of NSSO, Periodic Labour Force Survey (PLFS), Census of India and data published by NITI Aayog, Government of India. Other data sources are also used wherever necessary. The NSS reports of the 38th (1983), 43rd (1987-1988), 50th (1993-1994), 55th (1999-2000), 61st (2004-2005), 66th (2009-2010) and 68th (2011-2012) rounds along with PLFS (2017-2018) have been used to map the trends and patterns of female work force participation; sectoral shifts in women's employment and also to assess the quality of women's employment. NSS provides three different employment estimates based on three approaches to activity classification-usual status, current weekly status and current daily status. This paper uses the employment estimates based on usual status approach ${ }^{2}$ as it includes principal status (ps) and subsidiary status (ss). Further, the concept work participation rate (WPR) is used in this study to measure women's participation in the labour market. ${ }^{3}$ Statistical technique such as compound annual growth rate is used along with descriptive statistics for data analysis.

Trends in female labour force participation across many developed countries trace out a U-shaped curve of female labour supply. Goldin (1994) argues that

\footnotetext{
1 The United Nations Population Fund defines demographic dividend as 'the economic growth potential resulting from shifts in a population's age structure, mainly when the share of the working-age population (15 to 64) is larger than the share of non-working-age population (14 and younger, and 65 and older)'. India has a large youth population in the age group of 15 and 59 years, constituting about $64.4 \%$ of total population. https://www.gktoday.in/gk/demographic-dividend/, assessed 4 June 2019.

2 NSS (2011-2012) defines principal status (ps) as 'the activity status on which a person spent relatively long time during the 365 days preceding the date of survey' and subsidiary status (ss) as 'activity status on which a person spent a shorter time which is not less than 30 days, during the reference year'. If a person is working either under ps or ss, the person is counted under usual status (ps $+\mathrm{ss}$ ). Usual status approach is a more inclusive indicator for measuring labour force participation rate as it considers both the major time criterion and shorter time period.

3 Worker population ratio or work participation rate (WPR) is defined as the percentage of persons employed to total population (NSS 2011-2012).
} 
female labour force participation declines initially with economic development and then rises on account of structural shifts in the economy, decline in fertility rates and expansion of women's education resulting in a U-shaped curve of female labour supply. The Indian experience is very different as the female labour supply does not show the ' $U$ ' trajectory as found in most other countries. Many studies using NSS data have appeared in recent years in both India and abroad explaining the falling trend in women's employment with economic growth. The findings of most studies make it clear that work participation rates of women in India are declining on account of increase in household income and increase in enrolment of women in both rural and urban India (Chatterjee et al. 2015; Thomas 2012; Bhalla and Kaur 2011). Higher attendance in schools by girls has resulted in the withdrawal of mothers from labour force to look after the younger siblings (Krishna et al. 2016).

It has been pointed out that highly educated women are more likely to marry highly educated men earning high incomes, and hence remain out of the labour force (Chatterjee et al. 2018). Next, Hirway (2012) argues that with the incidence of poverty as high as $40 \%$, it is impossible for $85 \%$ of rural women and $89 \%$ of urban women to stay out of paid work. A few studies point out that the decline is owing to absence of employment opportunities, particularly for rural women, in non-farm sector (Ramesh and Srivastava 2014; Kannan and Raveendran 2012). There is also evidence that the mechanisation of agriculture has contributed to the decline in demand for female agricultural labour (Verick 2018). It is further claimed that large missing female labour force is owing to measurement fallacy and the difficulty of differentiating between domestic duties and contributing family work (Mehrotra 2015). Sociocultural norms as well, dissuade women's participation in labour force (Srivastava and Srivastava 2010). Thus, many factors influence the entry and exit of women from the labour market.

Studies also emphasise that a larger proportion of women are opting to stay out of the labour force mainly to attend to 'domestic duties', which clearly reflects the pressure of household and caring responsibilities on women (Rangarajan et al. 2011; Sudarshan and Bhattacharya 2009). According to the OECD report (2019), women in India spend on average 352 minutes a day on unpaid work as against 52 minutes by men. Findings of a few researches indicate that greater proportion of women workers are in the informal sector in India and are subject to high degrees of gender discrimination (Tiwari and Tiwari 2016; Sharma 2012 and Das 2012). Against this backdrop, the present research paper aims to look at the relationship between the growth of GDP and women's work participation in India; major structural changes in the Indian economy and resultant changes in the employment structure of women workforce; and also appraise the quality of women's labour in terms of select indicators.

\section{Female work participation rate in India}

Table 1 presents the WPR in India by the usual status. The WPR of women is not only low but is showing a falling trend since 2009-2010. Female WPR which was as high as $29.6 \%$ in 1983 had dropped to $16.5 \%$ in $2017-2018$, by 
Table 1 Trends in work participation rate (\%) in India by usual status ( $\mathrm{ps}+\mathrm{ss})$.

\begin{tabular}{|c|c|c|c|c|c|c|}
\hline \multirow[t]{2}{*}{ NSS rounds/period } & \multicolumn{3}{|c|}{ Male workers } & \multicolumn{3}{|c|}{ Female workers } \\
\hline & Rural & Urban & Total & Rural & Urban & Total \\
\hline 38th Round (1983) & 54.7 & 51.2 & 53.8 & 34.0 & 15.1 & 29.6 \\
\hline 43rd Round (1987-1988) & 53.9 & 50.6 & 53.1 & 32.3 & 15.2 & 28.5 \\
\hline 50th Round (1993-1994) & 55.3 & 52.1 & 54.5 & 32.8 & 15.5 & 28.6 \\
\hline 55th Round (1999-2000) & 53.1 & 51.8 & 52.7 & 29.9 & 13.9 & 25.9 \\
\hline 61st Round (2004-2005) & 54.6 & 54.9 & 54.7 & 32.7 & 16.6 & 28.7 \\
\hline 66th Round (2009-2010) & 54.7 & 54.3 & 54.6 & 26.1 & 13.8 & 22.8 \\
\hline 68th Round (2011-2012) & 54.3 & 54.6 & 54.4 & 24.8 & 14.7 & 21.9 \\
\hline PLFS (2017-2018) & 51.7 & 53.0 & 52.1 & 17.5 & 14.2 & 16.5 \\
\hline
\end{tabular}

Source: NSSO, 68th Round, Report No. 554, Employment and Unemployment Situation in India, 20112012 and Periodic Labour Force Survey, 2017-2018, Ministry of Statistics and Programme Implementation, National Statistical Office, Government of India

about 13 percentage points. During the entire period of 1983 to 2017-2018, there was an increase in WPR of women by three percentage points only between 1999-2000 and 2004-2005. The increase in female workforce in 2004-2005 has been attributed to a decline in the growth rate of agriculture which has increased the work participation rate of women mainly as unpaid family workers in the agriculture sector (Mehrotra and Sinha 2017). 'Added worker effect' theory also emphasises that women's participation in work force increases during economic crisis to supplement the declining household income (Chaudhary and Verick 2014; Abraham 2009). In absolute numbers also, the supply of female workers has drastically declined by 44.49 million during 2004-2005 and 2017-2018, which is a cause for concern. It is pertinent to note in this context that for the first time the NSSO statistics on the measurement of employment and unemployment situation in India shows a decline in the size of workforce in absolute numbers. The total number of workers has declined from 472.9 million in 2011-2012 to 457.4 million in 2017-2018. Much of the decline in the size of workers has happened in rural areas and among women workers which dropped from 101.8 million in 2011-2012 to 72.9 million in 2017-2018 (by 28.9 million). In urban India, female labour supply has increased by 3.86 million during the same period.

A closer look at the rural-urban composition of the women workforce reveals that rural women's WPR is much higher than their urban counterparts in all the periods of study. It is important to note that though the WPR of both women in rural and urban India is declining since 2009-2010, the rate of decline seems to be more rapid among rural than urban women. While for rural women the WPR declined from $32.7 \%$ in $2004-2005$ to $17.5 \%$ in $2017-2018$ (15 percentage points), for urban women it dropped from 16.6 to $14.2 \%$ (2.4 percentage points), during the same period. In the case of men, it is found that more than $50 \%$ of them are in the workforce in both rural and urban India over time, but even male 


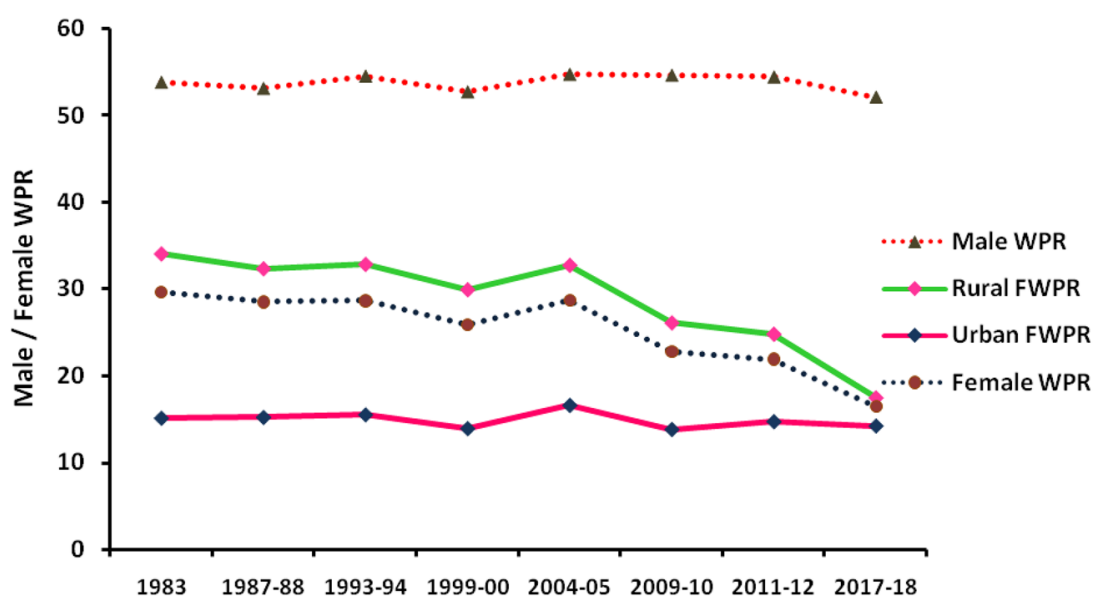

Fig. 1 Trends in male/female WPR in India. Source: NSSO, 68 ${ }^{\text {th }}$ Round, Report No. 554, Employment and Unemployment Situation in India, 2011-12 and Periodic Labour Force Survey, 2017-18, Ministry of Statistics and Programme Implementation, National Statistical Office, Government of India

WPR declined by two percentage points between 2011-2012 and 2017-2018. Figure 1 presents the trends in WPR of male and female workers in India.

The rural-urban gap in female WPR is shrinking, mainly due to the withdrawal of women workers in large numbers from the rural labour market. This gap has fallen from 19 percentage points in 1983 to three percentage points in 2017-2018. There exists male/female gap in WPR as well, and the difference is showing a rising tendency. The gap has expanded from 24 percentage points in 1983 to 36 percentage points in 2017-2018. The gender gap in WPR is relatively more in urban (39 percentage points) than rural India (34 percentage points), not because rural women are on equal footing with men but because of low work participation levels of urban women.

A study of age-wise WPR in India among female workers highlights that there is a continuous decline in WPR of girls in the age groups of 5-9 and 10-14 years in both rural and urban areas, which is a positive indicator of decline in the incidence of female child labour in the country. Further, it is seen that between 2011-2012 and 2017-2018, the WPR of women in the age group of 15-29 years has significantly declined by nine percentage points in rural and by five percentage points in urban areas. This decline may be due to increased enrolment of women in rural and urban India. The consistent rise in the WPR of women in rural and urban India in the age group 30-44 years during 1983 and 2017-2018 is a positive aspect as women's work force now consists largely of those in the productive age group. No definite pattern is found in the WPR of rural and urban women in the age group of 45-59 
Table 2 Age specific work participation rate of women in India by usual status.

\begin{tabular}{lrrrrrrrr}
\hline $\begin{array}{l}\text { Age group } \\
\text { (years) }\end{array}$ & 1983 & $\begin{array}{l}1987- \\
1988\end{array}$ & $\begin{array}{l}1993- \\
1994\end{array}$ & $\begin{array}{c}1999- \\
2000\end{array}$ & $\begin{array}{l}2004- \\
2005\end{array}$ & $\begin{array}{l}2009- \\
2010\end{array}$ & $\begin{array}{l}2011- \\
2012\end{array}$ & $\begin{array}{c}\text { PLFS } \\
2017- \\
2018\end{array}$ \\
\hline RURAL & & & & & & & & \\
5-9 & 1.0 & 1.0 & 0.5 & 0.3 & 0.2 & 0.2 & 0 & 0 \\
$10-14$ & 8.6 & 6.5 & 4.6 & 3.7 & 1.5 & 2.9 & 0.8 & 0.3 \\
$15-29$ & 37.3 & 37.8 & 36.3 & 34.5 & 29.1 & 30.9 & 30.2 & 21.2 \\
$30-44$ & 30.5 & 32.0 & 34.2 & 36.9 & 39.2 & 41.2 & 43 & 43.7 \\
$45-59$ & 18.1 & 18.2 & 19.3 & 19.3 & 23.0 & 20 & 21.6 & 28.3 \\
$60+$ & 4.6 & 4.5 & 5.1 & 5.3 & 7.0 & 4.8 & 4.4 & 6.5 \\
Total & 100 & 100 & 100 & 100 & 100 & 100 & 100 & 100 \\
URBAN & & & & & & & & 0 \\
5-9 & 0.5 & 0.3 & 0.3 & 0.1 & 0 & 0.2 & 0 & 0 \\
$10-14$ & 5.6 & 5.0 & 3.3 & 2.6 & 1.3 & 2.2 & 0.6 & 0.1 \\
$15-29$ & 36.0 & 35.1 & 32.6 & 32.2 & 27.1 & 31.4 & 30.4 & 25.1 \\
$30-44$ & 33.1 & 35.7 & 39.2 & 39.1 & 41.2 & 42.4 & 43.4 & 44.7 \\
$45-59$ & 19.0 & 19.0 & 19.9 & 20.2 & 23.2 & 19.2 & 20.9 & 24.7 \\
$60+$ & 5.8 & 4.9 & 4.7 & 5.8 & 7.2 & 4.6 & 4.7 & 5.5 \\
Total & 100 & 100 & 100 & 100 & 100 & 100 & 100 & 100 \\
\hline
\end{tabular}

Source: Same as in Table 1

and $60+$ years (see Table 2). The greatest concern in this context is the decline in the WPR of women in the age group $15+$ from $29 \%$ in $2011-2012$ to $22 \%$ in 2017-2018. ${ }^{4}$ Disaggregated data present an alarming trend of decline in the WPR of women in the age group 30-44 years in the more developed states of Karnataka, Gujarat, Tamil Nadu and Maharashtra, and also in low-income states of Bihar and Madhya Pradesh.

Analysing the unemployment figures among women for the period 1983 to 2017-2018, it is noticed that non-availability of jobs seems to be one of the prime factors accounting for decline in the WPR of women in India. Higher levels of female unemployment according to usual status were found in urban India. Unemployment rates have actually doubled for both rural and urban women between 2011-2012 and 2017-2018. For rural women, unemployment rate has increased from 1.6 to 3.8\% between 2011-2012 and 2017-2018, and for urban women, it has increased from 5 to $10.8 \%$ during the same period (see Table 3 ). A study of unemployment rates among young women (15-29 years) reveals that it has increased from $4.2 \%$ in $2004-2005$ to $13.6 \%$ in $2017-2018$ for rural women and from 14.9 to $27.2 \%$ for urban women during the same period. The increase has happened largely between 2011-2012 and 2017-2018. In rural areas, it has increased by nine percentage points, and in urban areas, it has increased by 14 percentage points (PLFS 2017-2018). A look at the recent unemployment data among the educated women indicates that there is over supply of educated

\footnotetext{
${ }^{4}$ WPR in the age group $15+$ is considered for global comparisons.
} 
Table 3 Unemployment rates according to usual status for women in India of ages 15+ with different educational attainment.

\begin{tabular}{|c|c|c|c|c|}
\hline Educational attainment & 2004-2005 & 2009-2010 & 2011-2012 & $\begin{array}{l}\text { PLFS } \\
2017- \\
2018\end{array}$ \\
\hline \multicolumn{5}{|l|}{ RURAL } \\
\hline Not literate & 0.2 & 0.0 & 0.2 & 0.1 \\
\hline Literate up to primary & 1.1 & 0.5 & 0.3 & 0.6 \\
\hline Middle & 3.4 & 2.3 & 2.5 & 3.7 \\
\hline Secondary and above & 15.2 & 11.8 & 9.7 & 17.3 \\
\hline All & 1.8 & 1.6 & 1.6 & 3.8 \\
\hline \multicolumn{5}{|l|}{ URBAN } \\
\hline Not literate & 0.3 & 0.9 & 0.4 & 0.8 \\
\hline Literate up to primary & 2.9 & 0.5 & 1.3 & 1.3 \\
\hline Middle & 8.0 & 3.7 & 3.0 & 5.1 \\
\hline Secondary and above & 15.6 & 12.2 & 10.3 & 19.8 \\
\hline All & 6.9 & 5.7 & 5.3 & 10.8 \\
\hline
\end{tabular}

Source: Same as in Table 1

women in relation to the growth of jobs for educated women that has resulted in lower WPR of women. While the unemployment rate for educated rural females (secondary and above) has increased from 9.7 to $17.3 \%$ between 2011-2012 and 2017-2018, it has increased from 10.3 to $19.8 \%$ for urban educated females (see Table 3).

\section{GDP Growth and Female WPR in India}

Economic growth means a rise in $\mathrm{GDP}^{5}$ or national income. Economic growth enables a country to raise its living standards through greater consumption of goods and services. According to IMF Report (2015), India turned out to be the fastest growing economy in the world with remarkable GDP growth rate of $7.9 \%$ in 2011. Linking GDP growth and female WPR in India, it is found that when GDP grew at $4 \%$ per annum during 1983 and 1987-1988, female employment registered a negative growth rate of $1 \%$ (refer Table 4). When GDP growth increased to $5.7 \%$, female employment growth also increased but by an insignificant rate of $0.1 \%$ during 1987-1988 and 1993-1994. Further increase in GDP growth by $6.8 \%$ during 1993-1994 and 2004-2005 was accompanied by a drop in female employment

\footnotetext{
5 GDP: Gross domestic product is defined as a measure in monetary terms, of the volume of all goods and services produced within the boundaries of a country during a given period of time, accounted without duplication. https://data.gov.in/keywords/gross-domestic-product, assessed 24 May 2019.
} 
Table 4 GDP and growth rate in GDP and female WPR in India.

\begin{tabular}{lllrrr}
\hline Period & $\begin{array}{l}\text { GDP at constant price } \\
(2004-2005) \text { Rs. in crores }\end{array}$ & & CAGR in GDP & \multicolumn{2}{l}{ CAGR in female WPR } \\
\cline { 3 - 6 } & & & Rural & Urban & Total \\
\hline $1983-1984$ & 936,270 & - & - & - & - \\
$1987-1988$ & $1,094,993$ & 3.99 & -1.27 & 0.17 & -0.94 \\
$1993-1994$ & $1,522,344$ & 5.65 & 0.26 & 0.33 & 0.06 \\
$1999-2000$ & $2,254,942$ & 6.77 & -1.53 & -1.80 & -1.64 \\
$2004-2005$ & $2,971,464$ & 5.67 & 1.81 & 3.61 & 2.07 \\
$2009-2010$ & $4,516,071$ & 8.73 & -4.41 & -3.63 & -4.50 \\
$2011-2012$ & $5,247,530$ & 7.79 & -2.52 & 3.21 & -1.99 \\
$2017-2018$ & $7,146,123$ & 5.28 & -5.65 & -0.58 & -4.61 \\
$1983-1984 / 2017-2018$ & - & 6.16 & -1.93 & -0.18 & -1.70 \\
\hline
\end{tabular}

CAGR, compound annual growth rate, calculated by the author

Source: NITI Aayog, National Statistics, http://niti.gov.in/content/national-statistics

growth by $1.6 \%$. Only between 1999-2000 and 2004-2005, the WPR of women recorded the highest growth rate of $2.1 \%$ when GDP growth rate dropped by one percentage point. When GDP growth rate touched the figure of 9\% in 2009-2010, female employment growth rate witnessed a considerable fall by $4.5 \%$. In the recent period (2017-2018), steep decline in the growth of GDP from 7.8\% in 2011-2012 to $5.3 \%$ was associated with an alarming drop in female employment growth by $5 \%$. Overall, while GDP growth rate was at $6 \%$, growth in female WPR was negative during 1983 and 2017-2018 which makes it clear that there is no significant relationship between economic growth and female WPR in India. Decline in female employment growth was more in rural $(2 \%)$ than urban India $(0.2 \%)$ during 1983-2018. Highest decline in female employment growth by $6 \%$ was recorded in 2017-2018 in rural India. Figure 2 clearly illustrates that there is no convex impact of GDP on female labour market participation. On the contrary, an inverted ' $U$ ' curve supply of female labour is observed in India.

\section{Structural Changes in the Indian Economy}

In the process of economic development, there is structural change ${ }^{6}$ in the economy. The concept 'structural change/transformation' was first introduced by Fisher (1939) and later developed by other economists (Kaldor 1957; Kuznets 1966). According to them, with the growth of an economy, the sectoral composition of output and employment undergo changes. Structural change results in a shift in the shares of GDP and labour force from the primary to secondary and tertiary sectors. Indian economy like many other developing countries has witnessed significant structural changes in recent years. An important change is the steady decline in the share of

\footnotetext{
${ }^{6}$ Structural change means change in the relative contribution of the three sectors to GDP and change in the sectoral share of employment.
} 


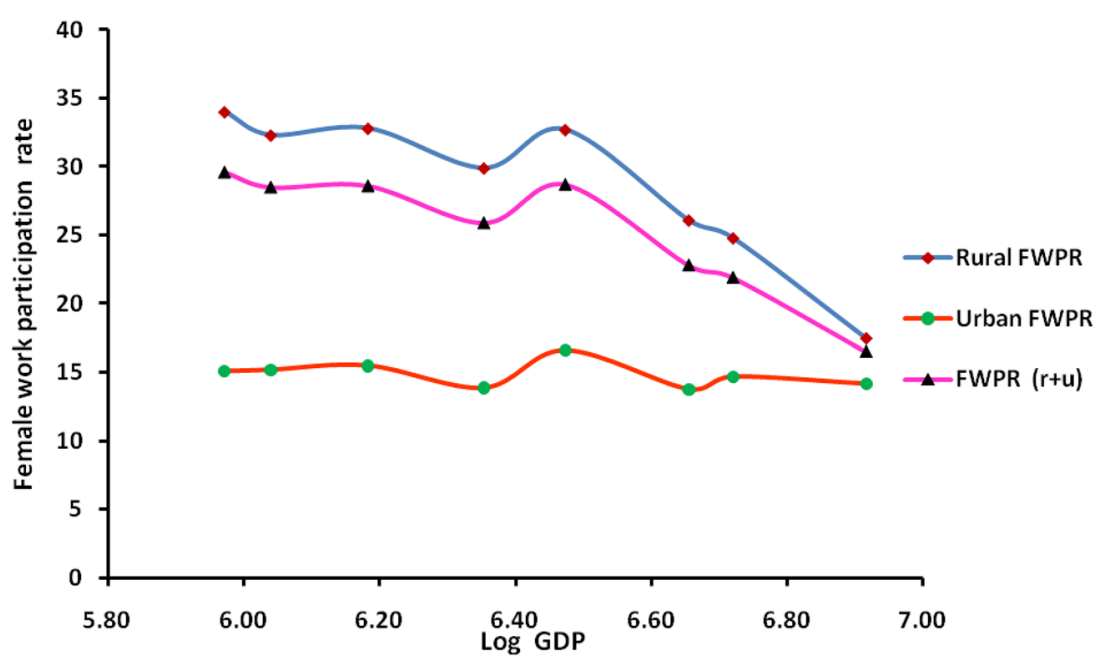

Fig. 2 GDP growth and female WPR in India. Source: NITI Aayog, National Statistics, http://niti.gov. in/content/national-statistics, NSSO, $68^{\text {th }}$ Round, Report No. 554, Employment and Unemployment Situation in India, 2011-12 and Periodic Labour Force Survey, 2017-18

the primary sector, which predominantly includes agriculture and allied activities, in GDP of India. Primary sector's contribution to GDP declined from $37.9 \%$ in 1983-1984 to $15.9 \%$ in 2017-2018, recording a negative growth rate of $2.5 \%$ per annum. The share of the secondary sector has gone up from $23.9 \%$ in 1983-1984 to $29.7 \%$ in $2017-2018$ registering an insignificant growth rate of $0.6 \%$ per annum. Tertiary sector's share in GDP has increased remarkably from 38\% in 1983-1984 to $54.4 \%$ in 2017-2018, recording a growth rate of $1 \%$ per annum (see Table 5).

The decreasing share of agriculture in GDP is a positive indicator, as it signifies a greater diversification and shift of resources from agriculture to non-agricultural sectors. The contribution of the agriculture sector to national income is less than $2 \%$ in many developed countries like USA, UK, Germany and Canada (IMF 2015). With high growth in India, the primary sector witnessed a rapid decline in its share of GDP; the tertiary sector has recorded a significant increase in its share, and the share of industrial sector rising at a slower pace over the decades (see Fig. 3).

\section{Changes in the Employment Structure of Women Workforce}

In response to changes in the relative share of the three sectors in GDP, women's employment has also shifted in the same direction from primary to tertiary sector, but the pace of change in women's employment seems to be slow. According to 2017-2018 (PLFS) data, agriculture continues to dominate women's employment $(57 \%)$ despite the decline in its share of GDP $(15.9 \%)$. Tertiary sector is the largest contributor to GDP (54\%), but its share in women's employment is $25 \%$. Secondary sector, the second highest contributor to GDP (30\%), accounts for $18 \%$ share of women's employment. A closer look at the rural and urban trends shows that the rate 
Table 5 Growth in sectoral share of GDP in India.

\begin{tabular}{llllrlr}
\hline Period & Primary & CAGR & Secondary & CAGR & Tertiary & CAGR \\
\hline $1983-1984$ & 37.9 & - & 23.9 & - & 38.3 & \multicolumn{1}{c}{-} \\
$1987-1988$ & 33.0 & -3.40 & 24.3 & 0.42 & 42.8 & 2.82 \\
$1993-1994$ & 31.5 & -0.77 & 23.7 & -0.42 & 44.8 & 0.76 \\
$1999-2000$ & 26.2 & -3.02 & 23.8 & 0.07 & 50.1 & 1.88 \\
$2004-2005$ & 21.9 & -3.52 & 25.1 & 1.07 & 53.1 & 1.17 \\
$2009-2010$ & 16.9 & -5.05 & 26.0 & 0.71 & 57.1 & 1.46 \\
$2011-2012$ & 16.5 & -1.19 & 26.1 & 0.19 & 57.4 & 0.26 \\
$2017-2018$ & 15.9 & -0.62 & 29.7 & 2.18 & 54.4 & -0.89 \\
CAGR (1983-2018) & -2.52 & & 0.64 & & 1.04 & \\
\hline
\end{tabular}

CAGR, calculated by the author

Source: Same as in Table 4

of decline in primary sector's share of women's employment is steeper (-3.44\%) in urban than rural areas $(-0.55 \%)$ owing to greater availability of non-farm work in urban regions (see Table 6).

In rural India, the secondary sector exhibited a rapid expansion in the share of female employment by six percentage points, from 7.1 to $13.4 \%$ between 1983 and 2017-2018, despite slow performance of secondary sector in GDP contribution. The share of the tertiary sector in rural women's employment seemed to be stagnant at 5\% in the initial periods and has displayed slow progress since 1999-2000 (see Fig. 4). While the tertiary sector shows an increasing share of income, the labour absorbing capacity by this sector seems to be low in rural areas. Urban women's employment in tertiary sector has expanded over time, from 38\% in 1983 to $61 \%$ in 2017-2018, showing a growth rate of $1.4 \%$ per annum. Women's employment share in secondary sector in urban areas remained stagnant at 30\% in 1983 as well as in 2017-2018. However, it varied between 29 and $34 \%$ over time mainly due to sluggish performance of secondary sector over the decades (see Fig. 5). In fact, the share of the secondary sector in employment of urban women has significantly dropped from $33.7 \%$ in $2011-2012$ to $29.9 \%$ in $2017-2018$.

A further disaggregation of women's employment by the three sectors shows that the structural changes in the Indian economy have not facilitated the intersectoral movement of women workers from primary to secondary and tertiary sectors. A large segment of India's working women in rural areas (73\%) continue to be engaged in agriculture and allied activities (2017-2018). There has, however, been a considerable increase in rural non-farm employment since 2004-2005; the biggest increase in the non-agricultural employment has been in the construction sector, where the share of employment in rural areas increased from $1.4 \%$ in $2004-2005$ to $6.6 \%$ in 2011-2012, though it declined to $5.3 \%$ in 2017-2018 owing to slowdown in real estate sector. However, the construction sector appears to absorb the bulk of female labour force exiting agriculture in rural India and it shows the maximum growth in women's employment (6.13\%) during 1983 and 2017-2018 (see Table 7). 


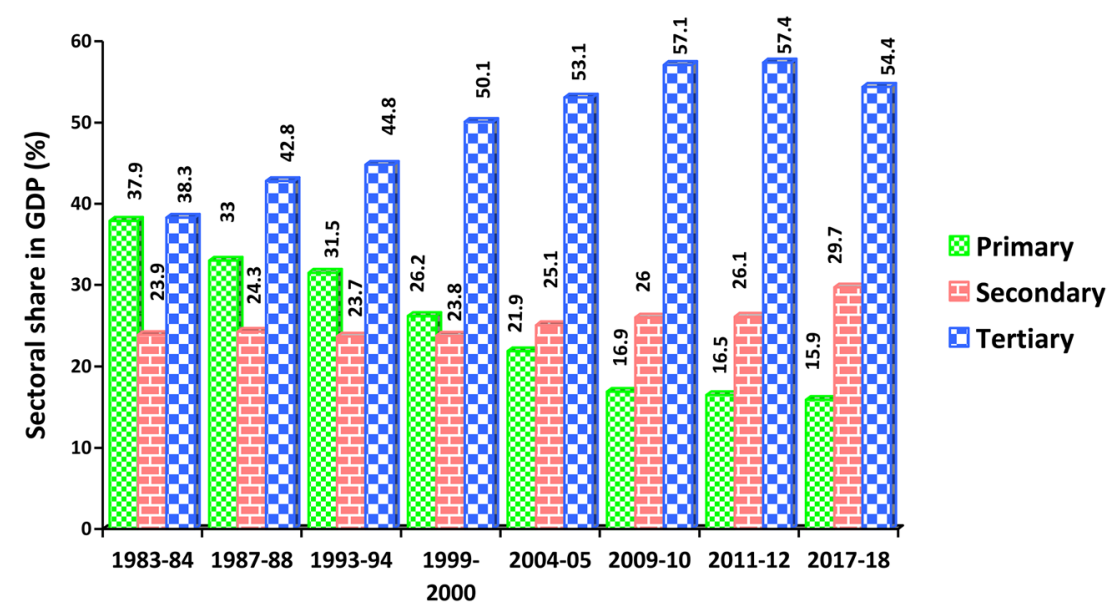

Fig. 3 Sectoral share of GDP in India over time. Source: NITI Aayog, National Statistics, http://niti.gov. in/content/national-statistics

Women's employment in trade, transport and other services in rural areas though has expanded; however, the rise is not significant for a period of 34 years. There is no major diversification in women's employment structure in rural areas. Lack of non-farm jobs on one side and lack of skills on the part of women workers to take up non-farm works on the other side impede the intersectoral movement of women workers. In urban India, the share of non-agricultural employment for women workers has increased from $69 \%$ in 1983 to $89 \%$ in 2011-2012 and further to 91\% in 2017-2018. The largest increase is accounted by the 'other services' sector. While the manufacturing sector's share in women's employment has dropped from $27 \%$ in 1983 to $25 \%$ in 2017-2018, the share of other services in urban women's employment has expanded significantly from $27.3 \%$ to $43.4 \%$ during the same period. In essence, urban women workers are more diversified than their rural counterparts with more than half of the workers diversifying into the tertiary sector. As India's development is led by service sector, the manufacturing sector has not been a driver of employment creation for women workers in urban and rural India.

\section{Quality of Women's Labour in India}

Nayyar (2012) has defined quality of employment on the basis of the three parameters - wages, the availability of written job contracts and the availability of social security benefits. Education also plays an important role in determining the quality of employment. As a higher educational level leads to higher earnings, the educated labour can be regarded as of better quality. In fact, earnings depend on productivity which in turn depends upon skills and experience. 
Quality of women's labour is assessed in this paper with regard to:

1. Sectoral distribution of workers - agriculture versus non-agriculture

2. Regularity of employment

3. Formal versus informal employment

4. Earnings of women workers

5. Literacy level of employed women workforce

\subsection{Agriculture Versus Non-agriculture Employment}

The share of agriculture sector in total women's employment shows a continuous decline. It had fallen from $77 \%$ in $1993-1994$ to $57 \%$ in $2017-2018$. In contrast, the non-agricultural sector shows a steady rise in women's employment from 23 to $43 \%$ during the same period (see Table 8 ). The concentration of $57 \%$ of women workers in agriculture clearly indicates the poor quality of women's labour because agriculture is a low productive sector with lower wages and high degree of informality in employment. Further, the statistics that in agriculture a sizeable proportion of women workers are employed as agricultural wage labourers (41\%) as against $24 \%$ cultivators, according to 2011 Census, presents the poor employment scenario of women in India.

\subsection{Regularity of Women's Employment}

It is generally perceived that regular wage and salary job is the quality employment because along with a regular job, workers also have job security and social security benefits (Ghose 2015; Papola and Sharma 2015). In casual employment, especially in the informal sector, there is absence of written job contracts and social security benefits, and for these reasons, casual jobs, especially in the informal sector, are considered to be of poor quality. Self-employment is a mixed segment as it includes own-account workers in large farms and enterprises, with high income as well as own-account workers in small/marginal farms and small/micro non-farm enterprises, often with lower levels of earnings. An important characteristic of women's employment in India is that high proportions of them are employed as casual labour. In rural areas, self-employment ${ }^{7}$ seems to be the dominant category of employment for women workers, followed by casual labour ${ }^{8}$ and then regular wage/salaried ${ }^{9}$ categories for the entire period 1983 to 2017-2018. However, the share of self-employment category declined from $61.9 \%$ in 1983 to

\footnotetext{
7 Self-employed are those who operate their own farm or non-farm enterprises or are engaged independently in a profession or trade on own-account or with one or a few partners (NSS 2011-2012).

8 A casual labour is a person who is casually engaged in others' farm or non-farm enterprises (both household and non-household) and, in return, receives wages according to the terms of the daily or periodic work contract (NSS 2011-2012).

9 Regular wage/salaried employees are persons who work in others' farm or non-farm enterprises (both household and non-household) and, in return, receive salary or wages on a regular basis (i.e. not on the basis of daily or periodic renewal of work contract) (NSS 2011-2012).
} 


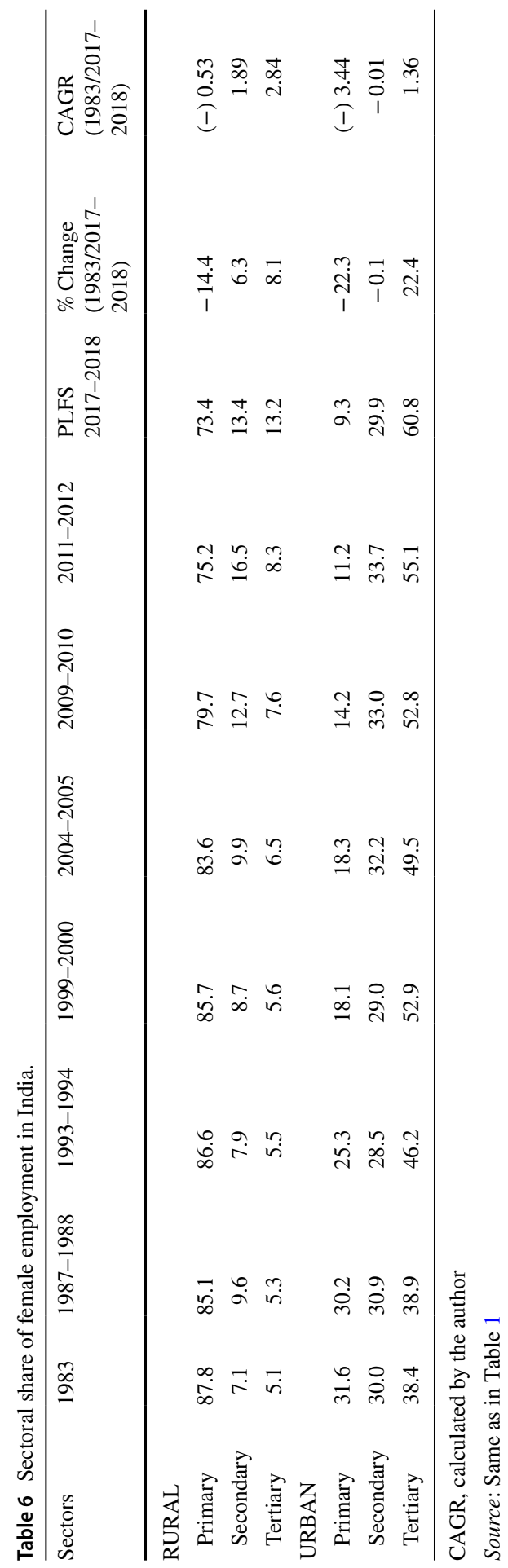




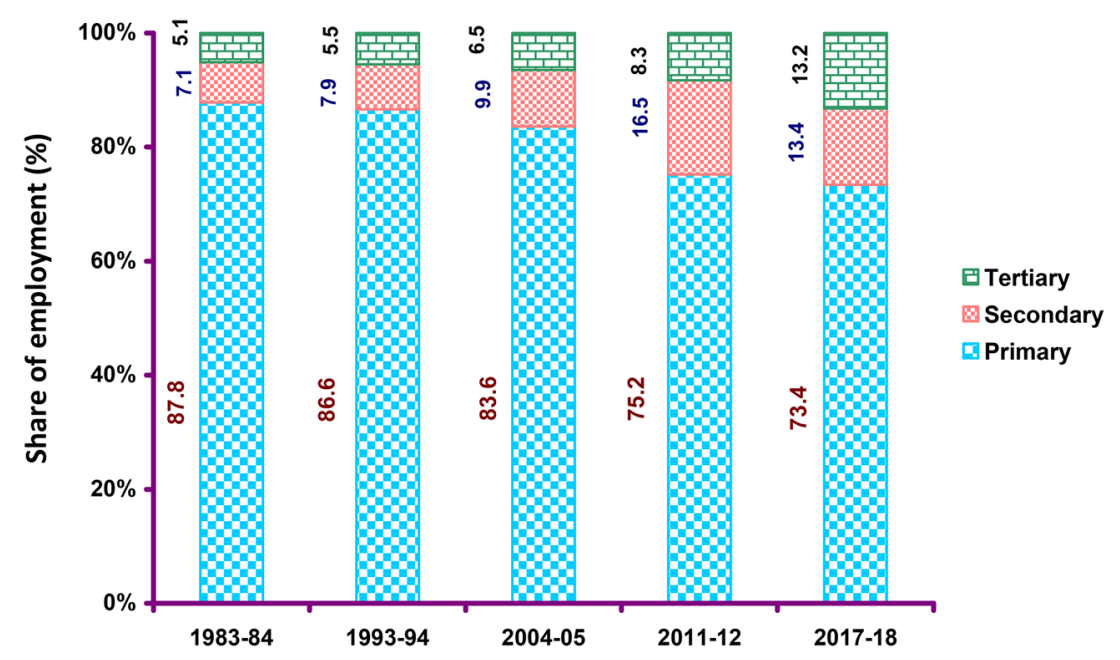

Fig. 4 Sectoral distribution of women workers (RURAL). Source: Various rounds of NSSO Report on Employment and Unemployment Situation in India and Periodic Labour Force Survey, 2017-18

59\% in 2011-2012 and further to $57.7 \%$ in 2017-2018, while the share of regular wage/salaried category, though relatively small, has increased considerably during this period. Despite the decline in the casual labour segment from 35\% in 1983 to $32 \%$ in $2017-2018$, this proportion is still high, indicating poverty among this segment of worker population (see Table 9).

In urban India, the share of casual labour has declined considerably from $28 \%$ in 1983 to $13 \%$ in 2017-2018. A significant feature noticed in urban India is the consistent increase in regular employment among women workers from $25.8 \%$ in 1983 to $52 \%$ in 2017-2018. In short, casual labour and self-employment segments are shrinking in urban areas and regular wage/salaried category is expanding, which is a positive aspect of improvement in the quality of women's labour. At the same time, rural women's employment scenario of shrinking self-employment and high incidence of casual labour is driven by the agrarian crisis in the economy. There is a steady decline in the size of agricultural land holdings. ${ }^{10}$ The prices of agricultural products have increased at a slower rate in comparison to non-agricultural products. Further cultivation has become unprofitable particularly for the small and marginal farmers due to rising input costs and wages. Most women farmers quitting agriculture have become casual labourers in construction, quarrying and brick kiln. Largescale male migration to urban areas in search of employment has also resulted in the growth of casual labour among women in rural areas.

\footnotetext{
10 The average area of land possessed by a rural household has fallen from 1 hectare in 1992-1993 to 0.65 hectare in 2010-2011. Further, while the proportion of rural households cultivating more than 0.40 hectares of land has decreased over the years from $43 \%$ in $1992-1993$ to $32 \%$ in $2010-2011$, the proportion of rural household cultivating less than 0.40 hectares has increased from 58 to $68 \%$ during the same period (NSS 2011-2012).
} 


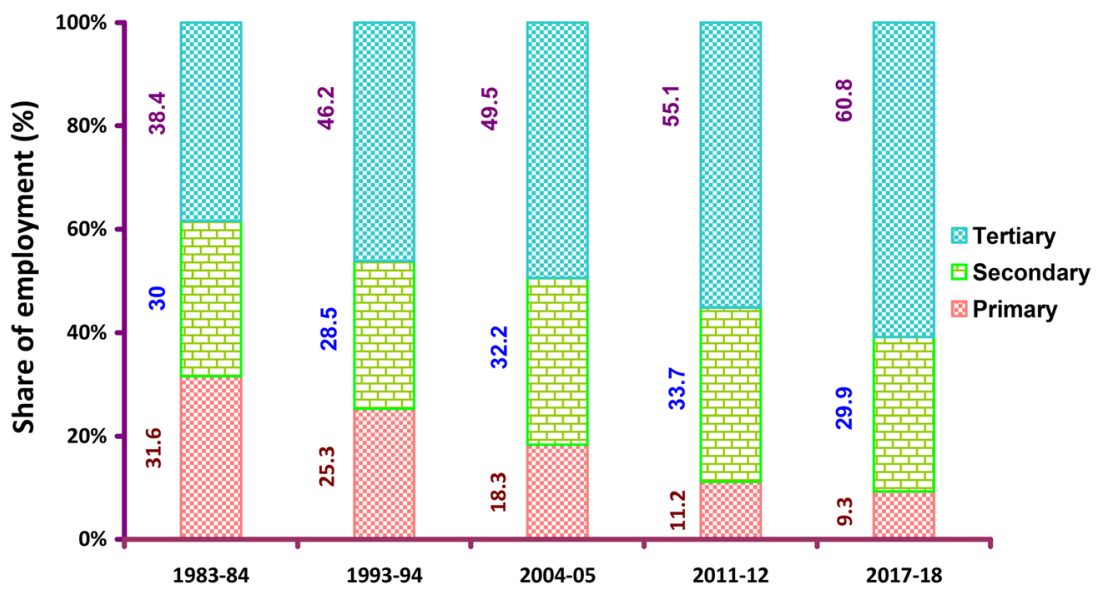

Fig. 5 Sectoral distribution of women workers (URBAN). Source: Same as in Fig. 4

\subsection{Sector Wise Status of Women Workers in India}

A study of the sectoral distribution of women workers by status of employment is imperative to understand which sector absorbs women largely as regular employed, casual labour and self-employed.

\subsubsection{Self-employment}

The percentage share of rural female workers engaged in self-employment in agriculture declined by 13 percentage points during 1993-1994 and 2017-2018. On the other side, self-employment in the non-agricultural sector displays a rising trend for rural females except for 2009-2010. In urban India, the share of self-employment in agriculture and non-agriculture has declined by six and five percentage points, respectively, between 1993-1994 and 2017-2018 (see Table 10).

\subsubsection{Regular Employment}

The proportion of women engaged in regular employment in agriculture seems to change very meagrely (less than 1\%) between 1993-1994 and 2017-2018 in both rural and urban India. A positive feature noticed is the continuous expansion of regular employment in non-farm sector for female workers in rural and urban areas. However, the increase in the share of this category is higher in urban (24 percentage points) than rural (eight percentage points), which suggests an improvement in the quality of women's labour especially in urban India. 


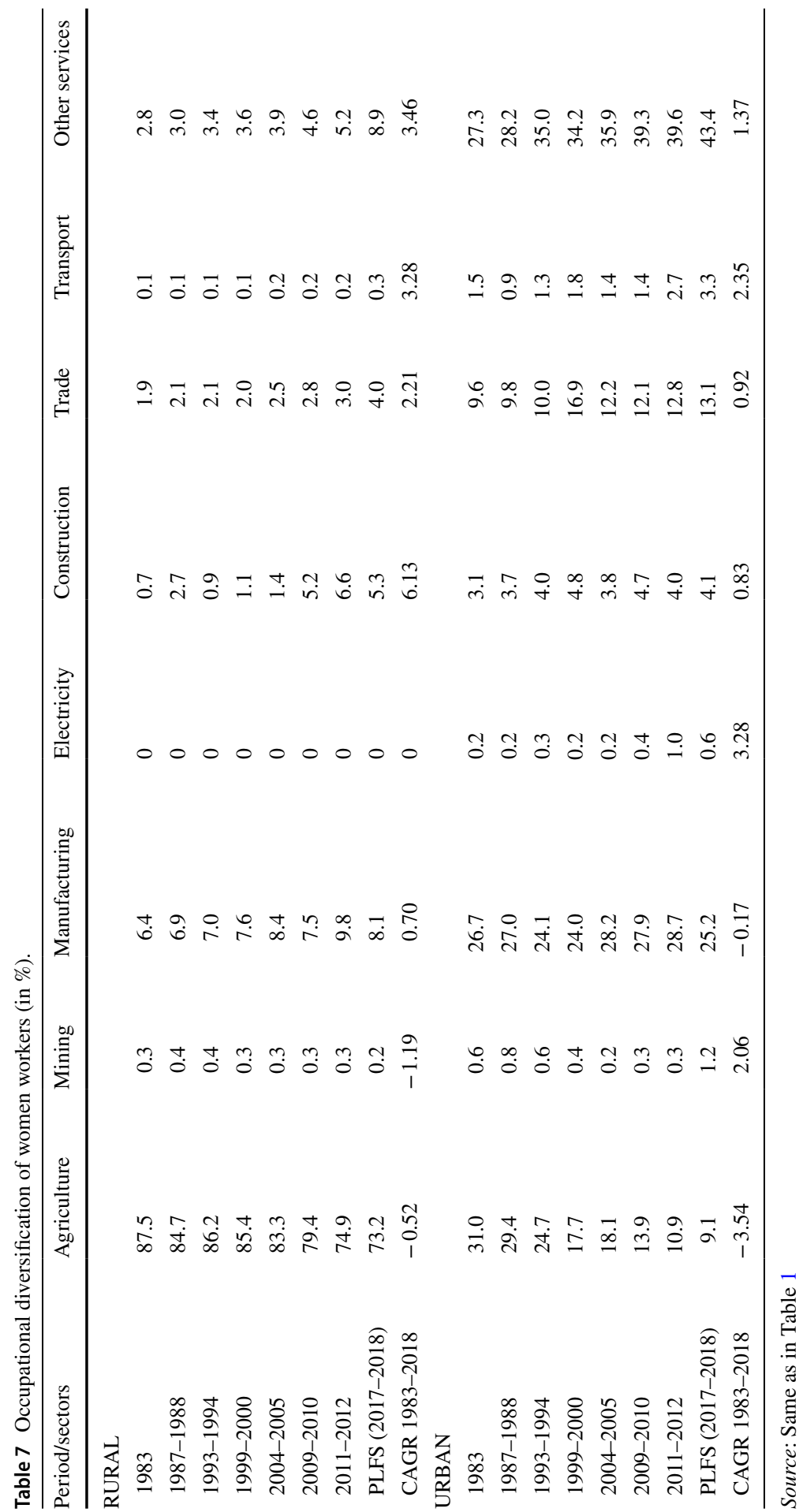




\subsubsection{Casual Labour}

Casual labour segment in agriculture, though, has declined for women in rural and urban areas; the rate of decline seems to be larger in rural areas (24 percentage points) than in urban areas (four percentage points). In contrast while in urban areas, there is a steady decline in casual labour segment among women in non-agriculture sector except for 2009-2010, in rural areas there is steady expansion of female casual labour in non-agriculture sector by 17.5 percentage points between 1993-1994 and 2017-2018. Overall, it is observed that the incidence of casual labour seems to be more rampant among women workers in rural India.

\subsection{Formal Versus Informal Sector Employment}

Formal employment is considered to be a better type of employment than the informal employment. ${ }^{11}$ The employees with informal jobs (NCEUS 2007) generally do not enjoy employment security (no protection against arbitrary dismissal), work security (no protection against accidents and illness at the work place) and social security (maternity and health care benefits, pension, etc.).

An ILO report (2018) highlights that among the five South Asian countries; informalisation of labour is the highest in India and Nepal (>90). Bangladesh (48.9\%), Sri Lanka (60.6\%) and Pakistan (77.6\%) seem to be better on this front. Informal employment accounts for substantial proportion of women's employment in India. The proportion of formal and informal sector employment among women was in the ratio of 8:92 in 2004-2005 and 9:91 in 2011-2012, indicating an increase in formal sector employment by $1 \%$. However, this increase in formal sector employment of women was largely informal in nature. While the formal employment in formal sector for women declined from 57\% in 2004-2005 to 51\% in 2011-2012, the share of informal employment in formal sector increased from $43 \%$ in 2004-2005 to $49 \%$ in 2011-2012 (see Table 11).

In the case of male workers, the composition of formal and informal employment seems to be in better ratio of 16:84 in 2004-2005 and 20:80 in 2011-2012. Like for female workers even for male workers, the increase in formal employment was mainly informal in nature. Nearly all employment for both male and female workers in informal sector was informal in nature in 2004-2005 and 2011-2012. The number of formally employed women workers declined from 6.9 million in 2004-2005 to 6.33 million in 2011-2012, and the informally employed women workers also dropped substantially from 141.7 million in $2004-2005$ to 122.8 million in

\footnotetext{
11 Informal sector in India is used as a synonym with unorganised sector. The National Commission for Enterprises in Unorganised Sector (NCEUS 2007) defines unorganised/informal sector as consisting of 'all unincorporated private enterprises owned by individuals or households engaged in the sale and production of goods and services operated on a proprietary or partnership basis with less than ten workers'. Informal employment/workers cover a broader category: it consists of those working in the unorganised sector or households, excluding regular workers with social security benefit provided by the employers, and the workers in the formal sector without any employment and social security benefits provided by the employers.
} 
Table 8 Women workers in agriculture versus nonagriculture employment by usual status (in \%).

\begin{tabular}{llllll}
\hline Period & \multicolumn{2}{l}{ Employed in agriculture } & \multicolumn{2}{l}{$\begin{array}{l}\text { Employed in non- } \\
\text { agriculture }\end{array}$} \\
\cline { 2 - 3 } \cline { 5 - 6 } \cline { 5 - 6 } & Male & Female & & Male & Female \\
\hline $1993-1994$ & 57.4 & 77.0 & & 42.6 & 23.0 \\
$1999-2000$ & 53.5 & 75.0 & & 46.5 & 25.0 \\
$2004-2005$ & 48.8 & 70.8 & & 51.2 & 29.2 \\
$2009-2010$ & 45.6 & 67.6 & & 54.4 & 32.4 \\
$2011-2012$ & 41.8 & 62.8 & & 58.2 & 37.2 \\
$2017-2018$ & 40.2 & 57.0 & & 59.8 & 43.0 \\
\hline
\end{tabular}

Source: Same as in Table 1

2011-2012. The bulk of this decline may be attributed to the overall decline in the supply of female workers from 148.6 million in 2004-2005 to 129.1 million in 2011-2012. According to the PLFS (2017-2018), about 55\% of females and 71\% of males are engaged in informal sector activities. The data of NSS and PLFS are not comparable in this aspect as the latter's coverage of informal workers excludes those engaged in household enterprises. ${ }^{12}$ Household enterprises constitute an important source of employment for women. In short, majority of the women work force $(95 \%)$ are in informal employment mainly because employment in informal sector is characterised by lower levels of education than the formal sector, and hence, women who are mostly educated up to secondary or higher secondary have access to the informal sector employment and secondly most women's self-employment is unpaid work.

\subsubsection{Sectoral Distribution of Women Workers in the Informal Sector}

Almost all employment (97\%) for women workers in agriculture sector is informal in nature in both rural and urban areas. More than $60 \%$ of women's work in non-farm sector is informal employment. Informality seems to be more prominent in women-oriented industries such as construction, retail trade and manufacture of tobacco products, textiles, apparels, food products, hotel and restaurants. In short, women concentrated agriculture, industries and services are more exposed to informal employment in India.

\subsubsection{Status of Informally Employed Women Workers}

Self-employment accounts for a sizeable share of the informally employed women workers in India during 2004-2005 and 2017-2018. However, it has declined in

\footnotetext{
$\overline{12}$ In PLFS report (2017-2018), informal sector includes only proprietary and partnership enterprises and the enterprise type 'employer's households' has been excluded from the coverage of workers in the informal sector.
} 
Table 9 Distribution of women workers by employment status.

\begin{tabular}{|c|c|c|c|c|c|c|}
\hline \multirow[t]{2}{*}{ Period } & \multicolumn{3}{|l|}{ RURAL } & \multicolumn{3}{|l|}{ URBAN } \\
\hline & $\begin{array}{l}\text { Self- } \\
\text { employed }\end{array}$ & $\begin{array}{l}\text { Regular } \\
\text { wage/ } \\
\text { salaried } \\
\text { employees }\end{array}$ & $\begin{array}{l}\text { Casual } \\
\text { labour }\end{array}$ & $\begin{array}{l}\text { Self- } \\
\text { employed }\end{array}$ & $\begin{array}{l}\text { Regular } \\
\text { wage/ } \\
\text { salaried } \\
\text { employees }\end{array}$ & Casual labour \\
\hline 1983 & 61.9 & 2.8 & 35.3 & 45.8 & 25.8 & 28.4 \\
\hline 1987-1988 & 60.8 & 3.7 & 35.5 & 47.1 & 27.5 & 25.4 \\
\hline 1993-1994 & 58.6 & 2.7 & 38.7 & 45.8 & 28.4 & 25.8 \\
\hline 1999-2000 & 57.3 & 3.1 & 39.6 & 45.3 & 33.3 & 21.4 \\
\hline 2004-2005 & 63.7 & 3.7 & 32.6 & 47.7 & 35.6 & 16.7 \\
\hline 2009-2010 & 55.7 & 4.4 & 39.9 & 41.1 & 39.3 & 19.6 \\
\hline 2011-2012 & 59.3 & 5.6 & 35.1 & 42.8 & 42.8 & 14.3 \\
\hline 2017-2018 & 57.7 & 10.5 & 31.8 & 34.7 & 52.1 & 13.1 \\
\hline $\begin{array}{l}\text { CAGR: } \\
\text { 1983/2017- } \\
2018\end{array}$ & $(-) 0.21$ & 3.96 & (-) 0.31 & (-) 0.81 & 2.09 & (-) 2.25 \\
\hline
\end{tabular}

Source: Same as in Table 1

both rural and urban areas. In rural India, it had declined from 77\% in 2004-2005 to $57.7 \%$ in $2017-2018$, and in urban India, it dropped from $47 \%$ in $2004-2005$ to $34.7 \%$ in $2017-2018$. While the share of informal employment among women employed in the regular wage/salaried segment increased by 12 percentage points in urban India between 2004-2005 and 2017-2018, it declined by four percentage points in rural areas during the period 2011-2012 and 2017-2018. Casual labour segment in total women's employment in informal sector increased significantly in rural areas by 19 percentage points, while its share in urban areas increased marginally by one percentage point during 2004-2005 and 2017-2018 (see Table 12).

\subsubsection{Condition of Women Workers in Informal Sector}

The self-employed workers are a heterogeneous segment and fall under three subgroups ${ }^{13}$-own-account workers, employers and helpers. Self-employment among

13 NSS (2011-2012) categorises self-employed persons into three subgroups:

1. Own-account workers Self-employed persons who operate their enterprises on their own account or with one or a few partners during the reference period, without hiring any labour are considered as own-account workers. They could, however, have unpaid helpers to assist them in the activity of the enterprise.

2. Employers Self-employed persons who worked on their own account or with one or a few partners and, who, by and large, ran their enterprise by hiring labour are considered as employers.

3. Helpers in household enterprise Self-employed persons who were engaged in their household enterprises, working full or part time and did not receive any regular salary or wages in return for the work performed, are considered as helpers in household enterprise. 
women workers is mostly in the form of own-account workers and helpers (unpaid workers). In 2004-2005, about 29\% of the self-employed women (rural and urban together) were own-account workers and another $26 \%$ were helpers and an insignificant proportion of women (0.3\%) were employers. In 2011-2012, own-account workers among self-employed women increased to $31.7 \%$, while the helpers group declined to $19.6 \%$ and employer category remains stagnant at $0.3 \%$ (see Table 12 ).

According to recent PLFS data (2017-2018), while own-account workers and employer segment have declined to $20 \%$ among women, helper category has increased to $32 \%$ which shows the reduced status of self-employed women in India in contrast to only $8 \%$ of men self-employed as helpers.

Region-wise data in this aspect show that self-employed women in helper category, which was $41 \%$ in 2004-2005 in rural areas, had fallen to $22 \%$ in 2011-2012 and again increased to 39\% in 2017-2018. Urban areas show a consistent decline in helper category of self-employed women. It has dropped from $21 \%$ in $2004-2005$ to $15 \%$ in $2011-2012$ and further to $11 \%$ in $2017-2018$ (see Fig. 6). What is distressing is the significant rise in the proportion of helper category of self-employed women workers in rural areas, by 17 percentage points in 2017-2018, which may be attributed to the growing unemployment in rural areas. The main advantage of self-employment of women in the 'helper' category is that women can easily combine domestic duties with unpaid work as the work place is the home. But the major drawback associated with this type of employment is that the job opportunities for women are restricted besides lower earnings.

Examining the condition of women workers in the informal sector (non-agriculture) under regular employment type (see Table 13), it is noticed that the proportion of women employed without any kind of written job contract increased from $59.6 \%$ in 2004-2005 to 66.8\% in 2017-2018. Rural-urban composition in this aspect shows that this category of job is dominant among urban women workers (71\%), than rural women workers (58.5\%). Nearly 48 to $50 \%$ of regularly employed rural and urban women in informal sector are not eligible for paid leave. About $60 \%$ of women, regularly engaged in informal sector activities, were not eligible for social security benefits such as provident fund, pension, gratuity, health care and maternity benefit in 2004-2005 in both rural and urban areas. This proportion has declined to $55 \%$ in rural and 50\% in urban India in 2017-2018. Thus, the condition of women workers engaged in the informal employment of non-agriculture sector is pathetic as more than 50\% are not eligible for paid leave and social security benefits and another $67 \%$ do not have any written job contract.

This feature in women's employment may be attributed to the overall employment trends in the economy. India's employment growth has not kept up with economic growth, and the situation is further worsened due to growing casualisation and informalisation of the workforce. The job creation in the past few years has been mainly in the informal sector, and about 14 million jobs were added in this sector during 2004-2005 and 2011-2012 (Himanshu 2017). Informality indicates inferior job quality. Further, the higher casual labour segment among informally employed women workers suggests the lower quality of women's labour. They are the poorest among poor due to irregular work, unstable income and lower earnings. In fact, they constitute the vulnerable segment of worker population. 


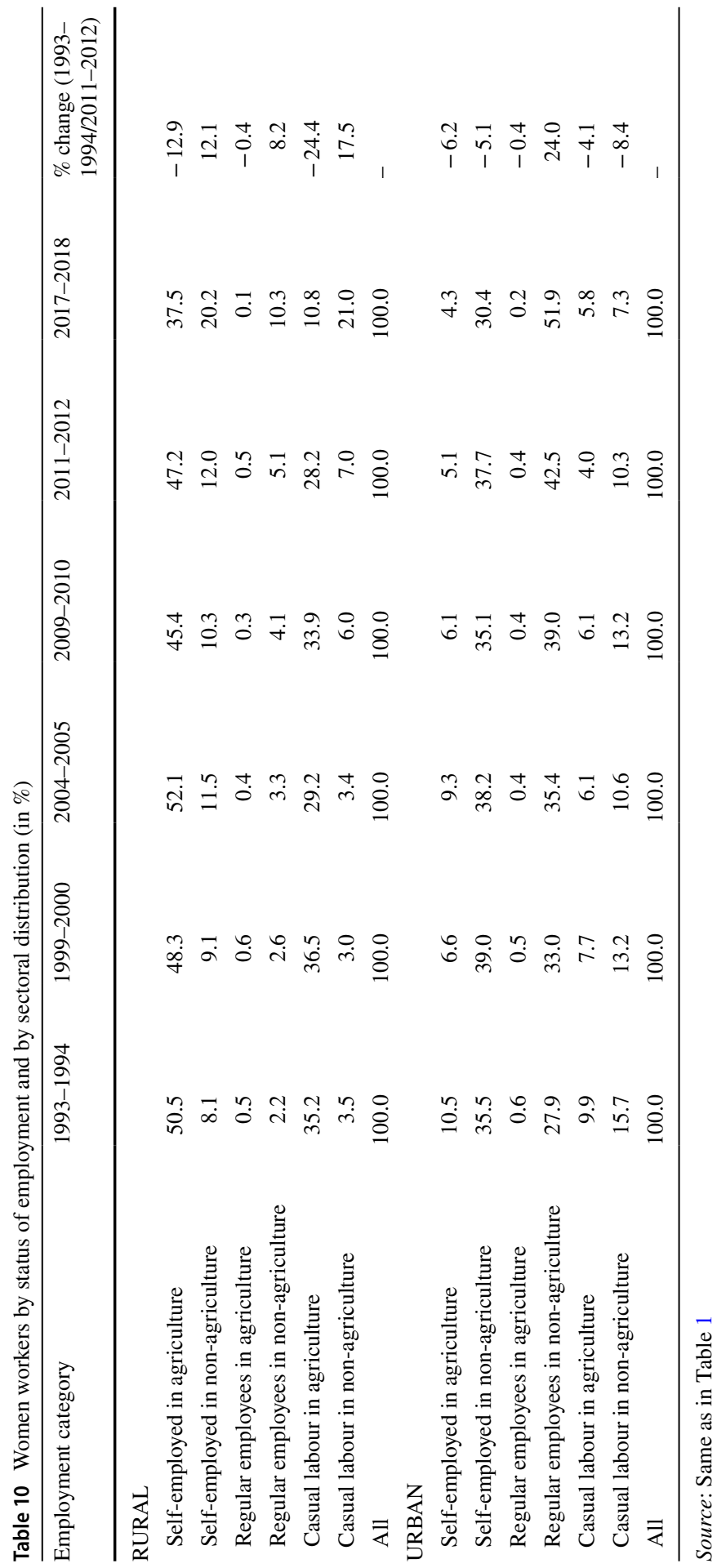


Table 11 Formal and informal employment across formal and informal sectors in India (in million).

\begin{tabular}{|c|c|c|c|c|c|c|c|}
\hline \multirow[t]{2}{*}{ Employment/sectors } & \multicolumn{3}{|c|}{ Formal sector } & \multicolumn{3}{|c|}{ Informal sector } & \multirow[t]{2}{*}{ Grand total } \\
\hline & Male & Female & Total & Male & Female & Total & \\
\hline \multicolumn{8}{|l|}{ 2004-2005 } \\
\hline $\begin{array}{l}\text { Formal employment } \\
\text { (in million) }\end{array}$ & $\begin{array}{l}25.36 \\
(50.9)\end{array}$ & $\begin{array}{l}6.7 \\
(56.8)\end{array}$ & $\begin{array}{l}32.06 \\
(52)\end{array}$ & $\begin{array}{l}1.24 \\
(0.5)\end{array}$ & $\begin{array}{l}0.2 \\
(0.1)\end{array}$ & $\begin{array}{l}1.44 \\
(0.4)\end{array}$ & $\begin{array}{l}33.5 \\
(7.3)\end{array}$ \\
\hline $\begin{array}{l}\text { Informal employment } \\
\text { (in million) }\end{array}$ & $\begin{array}{l}24.44 \\
(49.1)\end{array}$ & $\begin{array}{l}5.1 \\
(43.2)\end{array}$ & $\begin{array}{l}29.54 \\
(48)\end{array}$ & $\begin{array}{l}258.3 \\
(99.5)\end{array}$ & $\begin{array}{l}136.6 \\
(99.9)\end{array}$ & $\begin{array}{l}394.9 \\
(99.6)\end{array}$ & $\begin{array}{l}424.4 \\
(92.7)\end{array}$ \\
\hline Total & $\begin{array}{l}49.8 \\
(16.1)\end{array}$ & $\begin{array}{l}11.8 \\
(7.9)\end{array}$ & $\begin{array}{l}61.6 \\
(13)\end{array}$ & $\begin{array}{l}259.5 \\
(83.9)\end{array}$ & $\begin{array}{l}136.8 \\
(92.1)\end{array}$ & $\begin{array}{l}396.3 \\
(87)\end{array}$ & $\begin{array}{l}457.9 \\
(100)\end{array}$ \\
\hline \multicolumn{8}{|l|}{$2011-2012$} \\
\hline $\begin{array}{l}\text { Formal employment } \\
\text { (in million) }\end{array}$ & $\begin{array}{l}30.98 \\
(44.4)\end{array}$ & $\begin{array}{l}6.2 \\
(51.1)\end{array}$ & $\begin{array}{l}37.18 \\
(45.4)\end{array}$ & $\begin{array}{l}1.26 \\
(0.5)\end{array}$ & $\begin{array}{l}0.13 \\
(0.1)\end{array}$ & $\begin{array}{l}1.39 \\
(0.4)\end{array}$ & $\begin{array}{l}38.57 \\
(8.2)\end{array}$ \\
\hline $\begin{array}{l}\text { Informal employment } \\
\text { (in million) }\end{array}$ & $\begin{array}{l}38.8 \\
(55.6)\end{array}$ & $\begin{array}{l}5.94 \\
(48.9)\end{array}$ & $\begin{array}{l}44.74 \\
(54.6)\end{array}$ & $\begin{array}{l}272.66 \\
(99.5)\end{array}$ & $\begin{array}{l}116.83 \\
(99.9)\end{array}$ & $\begin{array}{l}389.49 \\
(99.6)\end{array}$ & $\begin{array}{l}434.23 \\
(91.8)\end{array}$ \\
\hline Total & $\begin{array}{l}69.78 \\
(20.3)\end{array}$ & $\begin{array}{l}12.14 \\
(9.4)\end{array}$ & $\begin{array}{l}81.92 \\
(17.3)\end{array}$ & $\begin{array}{l}273.93 \\
(79.7)\end{array}$ & $\begin{array}{l}116.96 \\
(90.6)\end{array}$ & $\begin{array}{l}390.89 \\
(82.7)\end{array}$ & $\begin{array}{l}472.81 \\
(100)\end{array}$ \\
\hline Employment/sectors & & & & Male & & & Female \\
\hline \multicolumn{8}{|l|}{$2017-2018 *$} \\
\hline Formal employment $(\%)$ & & & & 28.9 & & & 45.2 \\
\hline Informal employment $(\%)$ & & & & 71.1 & & & 54.8 \\
\hline
\end{tabular}

Figures in brackets are percentage to total

*In PLFS (2017-2018), Informal sector includes only proprietary and partnership enterprises and excludes household enterprises

Source: NSS (2004-2005 and 2011-2012), Informal Sector and Conditions of Employment in India and PLFS (2017-2018)

\subsection{Earnings of Women Workers}

There exists large pay gap in the earnings of male and female workers in all categories of employment in rural and urban India. In the case of regular workers, the per day earnings gap between male and female workers is relatively more in rural than urban areas except in 1999-2000. The gender gap in the earnings of casual labour seems to be more prominent in urban than rural areas. This feature is not due to greater wage parity among workers in rural areas, but due to lower wages of rural male workers. The results indicate that on an average rural women's pay is $27 \%$ less than that of men in regular employment and in casual labour, rural women earn $35 \%$ less compared to men. In urban India, women's earnings are $19 \%$ less than that of men in regular employment and in casual labour women's pay is $41 \%$ less compared to men. Thus, the lower earnings of women show the poor quality of women's labour in the country (see Table 14). It is important to note that while the earnings gap is narrowing for regular workers it is expanding significantly for casual labour segment between 2011-2012 and 2017-2018, which is an indication of increased economic disparity in the labour market. 
Table 12 Status of informally employed workers in India (in \%).

\begin{tabular}{|c|c|c|c|c|c|c|}
\hline \multirow[t]{2}{*}{ Employment category } & \multicolumn{2}{|l|}{ Rural } & \multicolumn{2}{|c|}{ Urban } & \multicolumn{2}{|l|}{ Total } \\
\hline & Male & Female & Male & Female & Male & Female \\
\hline \multicolumn{7}{|l|}{ 2004-2005 } \\
\hline \multicolumn{7}{|l|}{ Self-employment } \\
\hline (a) Own-account worker & 40.2 & 35.5 & 32.8 & 26.1 & 36.9 & 29.1 \\
\hline (b) Employer & 0.8 & 0.1 & 2.8 & 0.5 & 1.8 & 0.3 \\
\hline (c) Helper & 8.5 & 40.9 & 7.9 & 20.8 & 7.7 & 26.1 \\
\hline Total self-employed & 49.5 & 76.5 & 43.5 & 47.4 & 46.4 & 55.5 \\
\hline Regular employment & 22.6 & 10.8 & 42.6 & 40.5 & 32.3 & 28.7 \\
\hline Casual labour & 27.9 & 12.7 & 13.9 & 12.1 & 21.3 & 15.8 \\
\hline Total & 100 & 100 & 100 & 100 & 100 & 100 \\
\hline \multicolumn{7}{|l|}{ 2011-2012 } \\
\hline \multicolumn{7}{|l|}{ Self-employment } \\
\hline (a) Own-account worker & 33.1 & 34.5 & 31.3 & 27.3 & 32.2 & 31.7 \\
\hline (b) Employer & 0.9 & 0.3 & 2.6 & 0.3 & 1.7 & 0.3 \\
\hline (c) Helper & 5.3 & 22.3 & 6.5 & 15 & 5.9 & 19.6 \\
\hline Total self-employed & 39.3 & 57.1 & 40.4 & 42.6 & 39.8 & 51.6 \\
\hline Regular employment & 22.7 & 14.7 & 45.3 & 46.2 & 33.6 & 26.7 \\
\hline Casual labour & 38.0 & 28.2 & 14.3 & 11.2 & 26.6 & 21.7 \\
\hline Total & 100 & 100 & 100 & 100 & 100 & 100 \\
\hline \multicolumn{7}{|l|}{ 2017-2018 } \\
\hline \multicolumn{7}{|l|}{ Self-employment } \\
\hline $\begin{array}{l}\text { (a) Own-account worker and } \\
\text { employer }\end{array}$ & 48.0 & 19.0 & 34.9 & 23.7 & 44.1 & 20.2 \\
\hline (b) Helper & 9.8 & 38.7 & 4.3 & 11.0 & 8.2 & 31.7 \\
\hline Total self-employed & 57.8 & 57.7 & 39.2 & 34.7 & 52.3 & 51.9 \\
\hline Regular employment & 14.0 & 10.5 & 45.7 & 52.1 & 23.4 & 21.0 \\
\hline Casual labour & 28.2 & 31.8 & 15.1 & 13.2 & 24.3 & 27.1 \\
\hline Total & 100 & 100 & 100 & 100 & 100 & 100 \\
\hline
\end{tabular}

Source: Same as in Table 11

Gender gap in wages persists in the Indian labour market as found worldwide. The wage disparity is quite striking in casual labour than regular employment in urban areas and a reverse trend is noticed in rural areas, where gender gap in earnings is more rampant in regular than casual employment. The results suggest that the lower earnings of women may be attributed to labour market discrimination. Employers segregate the jobs as 'male jobs' and 'female jobs' and fix a lower wage for female jobs and conveniently evade the provisions of the Equal Remuneration Act, 1976 according to which it is mandatory to pay equal wages for equal work. 


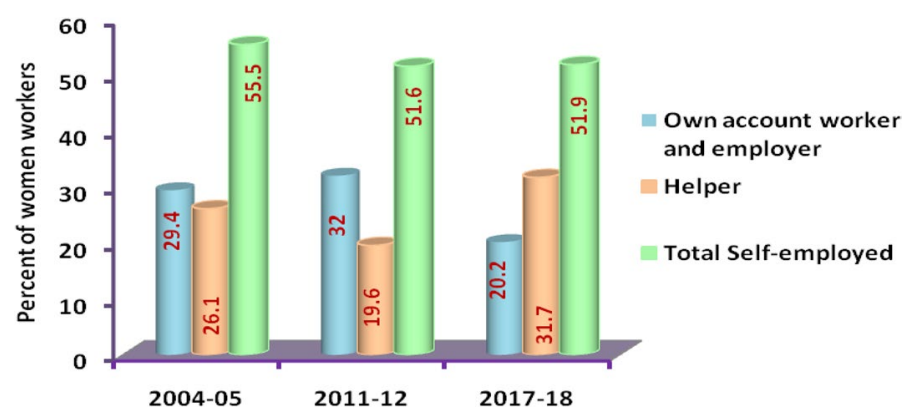

Fig. 6 Status of self-employed women workers in India. Source: NSSO (2004-05 and 2011-12), Informal Sector and Conditions of Employment in India and Periodic Labour Force Survey, 2017-18

\subsection{Literacy Level of Employed Women}

An analysis of WPR of women by their educational level shows that women's WPR is relatively higher among the illiterate group between 1983 and 2017-2018 in rural and between 1983 and 2011-2012 in urban areas which clearly indicate not only the poor quality of women's employment status but also accounts for lower earnings of women (see Figs. 7, 8). Next to illiterate, women with primary and middle level education display higher levels of WPR in both rural and urban areas.

An encouraging trend noticed is that the share of illiterate women in total women workforce is dropping. It declined from 85 to $29 \%$ in rural and from 59 to $22 \%$ in urban areas between 1983 and 2017-2018. The recent data on female WPR by educational level (2017-2018) show that the quality of women's labour in terms of educational qualification seems to be better in urban India with about one-third of women workforce having educational qualification of graduation and above, whereas the corresponding figure for rural India is only $13 \%$.

The statistics that women work force in India is still dominated by the illiterate group clearly implies the poor quality of women's labour. Figure 9 clearly demonstrates that with expansion of female literacy, there is no commensurate improvement in FWPR. On the contrary, there is a steady decline in the WPR of rural women with increase in educational levels as revealed by the downward sloping trajectory of female labour supply. This leads to the question as to why women's education has not translated to increased labour market participation. Is it because women desire domestic duties to paid work or suitable jobs are unavailable to them.

Young females (15-29 years) attending to domestic duties has increased from 45.9\% in 2004-2005 to 52.3\% in 2017-2018 (PLFS). Similarly, in the productive age group 30 to 59 years, the proportion of females attending to domestic duties has increased from $46 \%$ in $2004-2005$ to $65.4 \%$ in $2017-2018$. Overall for the age group 15-59 years, it is observed that less than $1 \%$ of males and about $60 \%$ of females were outside the labour market attending to domestic duties only. Examining the educational levels of women attending to domestic duties shows that women with middle and secondary level education were largely engaged in domestic duties compared to highly educated women (PLFS 2017-2018). 
Table 13 Condition of women workers in informal sector (regular workers in nonagriculture sector).

\begin{tabular}{|c|c|c|c|c|c|c|}
\hline \multirow[t]{2}{*}{ Period } & \multicolumn{2}{|l|}{ Rural } & \multicolumn{2}{|c|}{ Urban } & \multicolumn{2}{|c|}{ Rural+ Urban } \\
\hline & Male & Female & Male & Female & Male & Female \\
\hline \multicolumn{7}{|c|}{ Employees who had no written job contract } \\
\hline $2004-2005$ & 59.4 & 56.8 & 58.6 & 61.2 & 58.9 & 59.6 \\
\hline 2009-2010 & 61.1 & 55.3 & 65.1 & 64.8 & 63.7 & 61.5 \\
\hline 2011-2012 & 65.4 & 61.9 & 64.4 & 65.9 & 64.7 & 64.6 \\
\hline 2017-2018 & 71.7 & 58.5 & 72.7 & 71.4 & 72.3 & 66.8 \\
\hline \multicolumn{7}{|c|}{ Employees not eligible for paid leave } \\
\hline 2004-2005 & 47.3 & 48.7 & 44.8 & 48.0 & 45.8 & 48.3 \\
\hline 2009-2010 & 50.2 & 47.6 & 46.6 & 44.7 & 47.8 & 45.7 \\
\hline 2011-2012 & 51.7 & 48.1 & 49.5 & 49.1 & 50.2 & 48.8 \\
\hline 2017-2018 & 58.1 & 47.9 & 53.1 & 51.8 & 55.2 & 50.4 \\
\hline \multicolumn{7}{|c|}{ Employees not eligible for any social security benefits* } \\
\hline 2004-2005 & 55.5 & 60.8 & 51.9 & 59.6 & 53.2 & 60.0 \\
\hline 2009-2010 & 55.8 & 61.5 & 52.9 & 53.0 & 53.9 & 56.0 \\
\hline 2011-2012 & 56.8 & 63.4 & 53.5 & 56.2 & 54.7 & 58.7 \\
\hline 2017-2018 & 51.9 & 55.1 & 47.0 & 50.1 & 49.0 & 51.8 \\
\hline
\end{tabular}

*Social security benefits considered are provident fund, pension, gratuity, health care and maternity benefit

Source: PLFS (2017-2018)

\section{Conclusion}

To sum up, on account of a rise in GDP and structural changes in Indian economy there is neither quantitative nor qualitative improvement in women's employment over time. In terms of numbers, the female labour supply has fallen. The decline in women work force has occurred largely in rural areas and is also found to be higher among women in the age group 15-29 years. There is no ' $U$ ' curve of female labour supply in response to GDP growth, implying that female labour market participation cannot be interpreted in terms of economic variables as it is also influenced by non-economic factors. There is no major occupational diversification in women's employment consequent upon sectoral transformation of the economy from primary to the tertiary sector. Agriculture is still the principal sector in women's employment in India despite considerable decline in its share in GDP. Urban scenario seems to be better as more women are now seen in trade, transport and other services. The study finds that the quality of women's labour in India is poor. Concentration of workforce in agriculture sector as wage labourers, lower wages, large-scale informal employment, poor literacy levels and most self-employed women engaged as unpaid workers are indications of women's disadvantage position and economic disparity in the labour market. A country's economic development depends upon the work participation of women. In addition, to reap the benefits of demographic dividend and for economic empowerment women's labour market participation is important. If adequate steps are not taken to improve the supply of female labour then there 
Table 14 Average wage/salary earnings per day (in Rs.) received by regular and casual workers of age $15+$

\begin{tabular}{|c|c|c|c|c|c|c|}
\hline \multirow[t]{2}{*}{ Period } & \multicolumn{2}{|l|}{ Rural } & \multirow{2}{*}{$\begin{array}{l}\text { Gender gap in } \\
\text { rural India }\end{array}$} & \multicolumn{2}{|l|}{ Urban } & \multirow{2}{*}{$\begin{array}{l}\text { Gender gap in } \\
\text { urban India }\end{array}$} \\
\hline & Male & Female & & Male & Female & \\
\hline \multicolumn{7}{|c|}{ Earnings per day of regular workers } \\
\hline 1993-1994 & 58.48 & 34.89 & 23.59 & 78.12 & 62.31 & 15.81 \\
\hline 1999-2000 & 127.32 & 114.01 & 13.31 & 169.71 & 140.26 & 29.45 \\
\hline 2004-2005 & 144.93 & 85.53 & 59.4 & 203.28 & 153.19 & 50.09 \\
\hline $2009-2010$ & 249.15 & 155.87 & 93.28 & 377.16 & 308.95 & 68.21 \\
\hline 2011-2012 & 322.28 & 201.56 & 120.72 & 469.87 & 366.15 & 103.72 \\
\hline $2017-2018$ & 451.00 & 328.00 & 123.00 & 600.00 & 485.00 & 115.00 \\
\hline \multicolumn{7}{|c|}{ Earnings per day of casual labour } \\
\hline 1993-1994 & 23.18 & 15.33 & 7.85 & 32.38 & 18.49 & 13.89 \\
\hline 1999-2000 & 45.48 & 29.39 & 16.09 & 63.25 & 38.22 & 25.03 \\
\hline 2004-2005 & 55.03 & 34.94 & 20.09 & 75.10 & 43.88 & 31.22 \\
\hline 2009-2010 & 101.53 & 68.94 & 32.59 & 131.92 & 76.73 & 55.19 \\
\hline 2011-2012 & 149.32 & 103.28 & 46.04 & 182.04 & 110.62 & 71.42 \\
\hline 2017-2018 & 267.00 & 173.00 & 94.00 & 324.00 & 192.00 & 132.00 \\
\hline
\end{tabular}

Source: Various rounds of NSS and PLFS (2017-2018)

\section{Not literate}

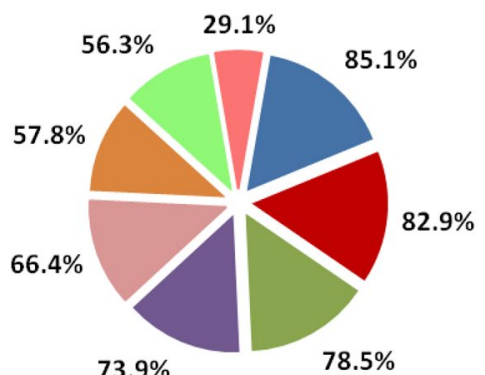

\section{Graduate and above}

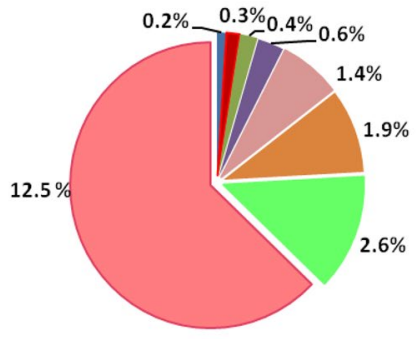

$\square 1983$

-1987-88

-1993-94

-1999-00

2004-05

2009-10

2011-12

$\square$ 2017-18

Fig. 7 Work participation rate of illiterate women and women with graduate and above education in rural India (15+). Source: Various rounds of NSSO Report on Employment and Unemployment Situation in India and Periodic Labour Force Survey, 2017-18

is the likelihood of large proportion of women staying out of workforce and the country would be experiencing jobless growth. State initiatives need to address the problem of growing unemployment among rural and urban women. An employment-oriented development strategy in manufacturing sector is needed to stimulate growth in female labour force participation rate in India and also to sustain economic growth in the long run. Education beyond secondary schooling needs to be promoted along with skill training and development-which is likely to increase the occupational choices of women and also improve the quality of women's labour. Investment on basic infrastructure such as provision of child 


\section{Not literate}

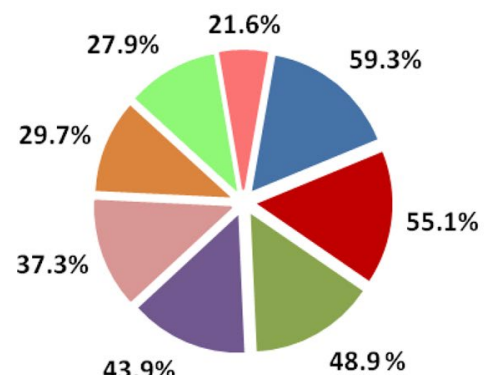

\section{Graduate and above}

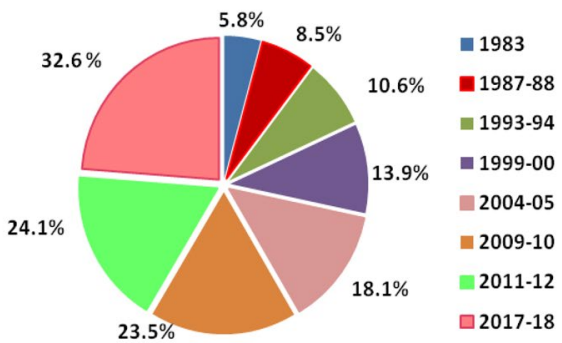

Fig. 8 Work participation rate of illiterate women and women with graduate and above education in urban India (15+). Source: Same as in Fig. 7
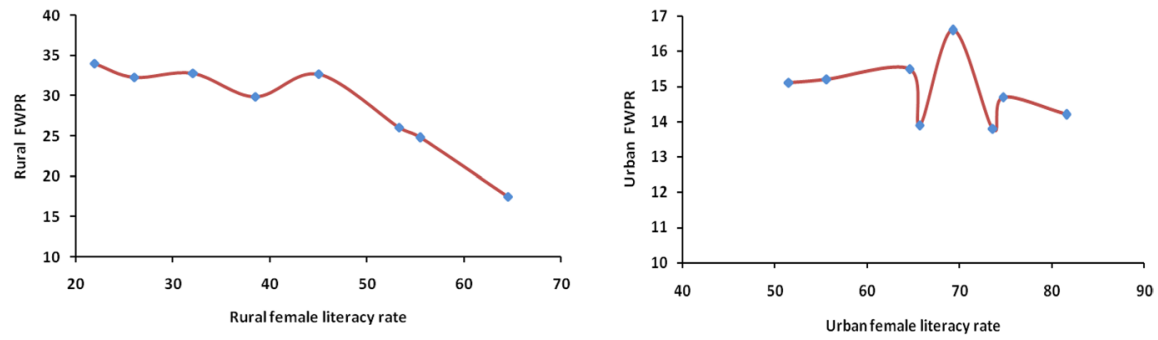

Fig. 9 Female literacy and female WPR in India. Source: Same as in Fig. 1

care, transport, water and sanitation is likely to increase female labour supply by increasing the time available for paid work. Above all, awareness needs to be created among women about the importance of their labour to the economy besides family. Efforts are also required to break the gender stereotyping of domestic work.

With current slowdown in growth of GDP due to COVID-19, we have to wait and see whether there will be a rise in female labour supply caused by economic distress or will there be greater withdrawal of women from workforce owing to growing unemployment in the country.

Acknowledgements This research paper is a part of my major research project titled 'Structural Changes in the Labour Market and Female Labour Force Participation in India: Theoretical Models, Empirical Evidence and Policy Implications'. I thank the Indian Council of Social Science Research (Grant No. 2-27/2017-18/SF), New Delhi, for the financial support towards this major research project. 


\section{References}

Abraham, V. 2009. Employment Growth in Rural India: Distress Driven? Economic and Political Weekly 44 (16): 97-104.

Bhalla, S., and R. Kaur. 2011. Labour Force Participation of Women in India: Some Facts, Some Queries. Working Paper No. 40, Asia Research Centre, London School of Economics. https:// eprints.1se.ac.uk/38367/ARCWP40-BhallaKaur.pdf. Accessed 5 Nov 2018.

Chatterjee, E., S. Desai, and R. Vanneman. 2018. Indian Paradox: Rising Education, Declining Women's Employment. India Human Development Survey, Working Paper No. 2018-1, NCAER and University of Mary land. https://www.demographic-research.org/volumes/vol38/31/defau lt.htm. Accessed 9 Jan 2019.

Chatterjee, U., R. Murgai, and M. Rama. 2015. Job Opportunities along the Rural-Urban Gradation and Female Labour Force Participation in India. Working Paper No.7412, World Bank, Policy Research. http://documents.worldbank.org/curated/en/732961468189870923/pdf/WPS7412.pdf. Accessed 23 May 2019.

Chaudhary, R., and S. Verick. 2014. Female Labour Force Participation in India and Beyond. Working Paper Series, ILO Asia Pacific. https://www.ilo.org/wcmsp5/groups/—asia/—ro-bangkok/—sronew_delhi/documents/publication/wcms_324621.pdf. Accessed 4 July 2019.

Das, P. 2012. Wage Inequality in India: Decomposition by Sector, Gender and Activity Status. Economic and Political Weekly 47 (50): 58-64.

Fisher, A.G.B. 1939. Production: Primary, Secondary and Tertiary. The Economic Record 15 (1): 24-38.

Goldin, C. 1994. The U-shaped Female Labour Force Function in Economic Development and Economic History. Working Paper No.4707, National Bureau of Economic Research. http:// www.nber.org/paper/w4707. Accessed 4 July 2019.

Ghose, A.K. 2015. Service-led Growth and Employment in India. In Labour, Employment and Economic Growth in India, ed. K.V. Ramaswamy, 57-90. Delhi: Cambridge University Press.

Himanshu, H. 2017. Growth, Structural Change and Wages in India: Recent Trends. The Indian Journal of Labour Economics 60 (3): 309-331.

Hirway, I. 2012. Missing Labour Force: An Explanation. Economic and Political Weekly 47 (37): $67-72$.

ILO. 2018. Women and Men in the Informal Economy: A Statistical Picture, (3rd edn.). https://www.ilo. org/wcmsp5/groups/public/dgreports/dcomm/documents/publication/wcms_626831.pdf. Accessed 20 June 2019.

IMF. 2015. World Economic Outlook. https://www.imf.org/en/Publications/WEO. Accessed 29 April 2019.

Kaldor, N. 1957. A Model of Economic Growth. The Economic Journal 67 (268): 591-624.

Kannan, K.P., and G. Raveendran. 2012. Counting and Profiling the Missing Labour Force. Economic and Political Weekly 47 (6): 77-80.

Krishna, K.L., A.A. Erumban, and D. Kusumdas. 2016. Structural Changes in Employment in India, 1980-2011. Working Paper No.262, Centre for Development Economics, Delhi School of Economics. http://www.cdedse.org/pdf/work262.pdf. Accessed 20 April 2019.

Kuznets, S. 1966. Modern Economic Growth: Rate, Structure, and Spread, 490-501. New Haven: Yale University Press.

Mehrotra, S. 2015. Why the Female Labour Force Participation is Low and Falling? https://www.resea rchgate.net/publication/29515719, doi:10.13140/R.2.1.4047.9841. Accessed 31 July 2019.

Mehrotra, S., and S. Sinha. 2017. Explaining Falling Female Employment During a High Growth Period. Economic and Political Weekly 52 (39): 54-62.

Nayyar, G. 2012. The Service Sector in India's Development, 146-180. Cambridge: Cambridge University Press.

NCEUS. 2007. National Commission for Enterprises in the Unorganised Sector, 2007. www.nceus.nic.in. Accessed 6 June 2019.

NSSO. 2011-2012. Employment and Unemployment Situation in India. Report No. 458, Ministry of Statistics and Programme Implementation, National Statistical Office, Government of India.

OECD. 2019. Breaking Down Barriers to Women's Economic Empowerment: Policy Approaches to Unpaid Care Work. https://www.oecd-ilibrary.org/development/breaking-down-barriers-to-women -s-economic-empowerment_c4ff3ddb-en. Accessed 2 Nov 2019. 
Papola, T.S., and A.N. Sharma. 2015. Labour and Employment in Fast Growing India: Issues of Employment and Inclusiveness. In Indian Economy Since Independence, ed. Uma Kapila, 725-806. New Delhi: Academic Foundation.

Periodic Labour Force Survey. 2017-2018. Annual Report, (2019), Ministry of Statistics and Programme Implementation, National Statistical Office, Government of India.

Ramesh, C., and S.K. Srivastava. 2014. Changes in the Rural Labour Market and Their Implications for Agriculture. Economic and Political Weekly 49 (10): 47-54.

Rangarajan, C., P.I. Kaul, and Seema. 2011. Where is the Missing Labour Force? Economic and Political Weekly 46 (39): 68-72.

Sharma, K. 2012. Role of Women in Informal Sector in India. Journal of Humanities and Social Science 4 (1): $29-36$.

Srivastava, N., and R. Srivastava. 2010. Women, Work and Employment Outcomes in Rural India. Economic and Political Weekly 45 (28): 49-63.

Sudarshan, R.M., and S. Bhattacharya. 2009. Through the Magnifying Glass: Women's Work and Labour Force Participation in Urban Delhi. Economic and Political Weekly 44 (48): 58-66.

Thomas, J.J. 2012. India's Labour Market during the 2000s: Surveying the Changes. Economic and Political Weekly 47 (51): 39-51.

Tiwari, R., and S. Tiwari. 2016. Women Employment in Unorganised Sector in India: An Empirical Analysis. Journal of Rural Development 35 (4): 645-664.

Verick, S. 2018. Female Labour Force Participation and Development. The Institute for the Study of Labour (IZA) Germany, World of Labour 2018: 87v2. https://doi.org/10.15185/izawol.87.v2.

Publisher's Note Springer Nature remains neutral with regard to jurisdictional claims in published maps and institutional affiliations. 